\title{
Analysis Of Students’ Error In Constructing Nominal Clause
}

\author{
Hermariyanti Kusumadewi \\ Pendidikan Bahasa Inggris \\ Universitas Indraprasta PGRI \\ Jl. Nangka No. 58 C Tanjung Barat, South Jakarta \\ Email: hermariyanti@gmail.com
}

\begin{abstract}
Nominal clause (noun clause) is a subordinate clause used as a noun in the sentence. A noun clause may be used as a subject or direct object of the verb, as a predicate noun, as object of the preposition, or as an appositive. The aims of this research is to analyze of students' error in constructing nominal clause. The urgency of the research on analyzing students' error in constructing noun clause proposes an urgent question: what type of errors that students make in constructing nominal clause? The answers are likely to provide some of the important things unsightly about the type of errors usually made by the students in constructing nominal clause. This research conducted qualitative method descriptively. The field research is used to collect the data. The third semester students at Indraprasta PGRI University are given a simple grammar test of nominal clause. The result shows that students made errors while contructing Nominal clause beginning with Question words, Nominal Clause with If/Whether, Nominal Clause with -that.
\end{abstract}

Key words: error, clause, nominal clause.

\section{INTRODUCTION}

Learning new language (English) seems not as a simple as making a smiling face picture on a paper, especially for people whose first language is not English, it needs a lot of effort to learn a foreign language. Despite of having different sounds of alphabet, there are many difficulties in the process of learning new language. Indonesians use bahasa Indonesia as their first and (or) second language, this is because most of people in Indonesia use their regional language as their mother tongue. When we come to this fact, it shows us another aspect which affecting the process of learning English.

Learning language means also mastering the skills and components of the language. In English, there are four skills to be mastered: listening, speaking, reading, and writing, and this also cannot be split up from language components. Based on this information, it means that to achieve the goal of learning English, learners should be mastered the language skills. Related to previous statements, it gives us a description how hard to learn foreign language with many differences from first language (L1) to the Target language.

Native speakers, on their own language, sometimes made mistakes. It can be found in the everyday used of English. Different from the native speakers, Foreign language learners do mistakes while learning English. This kind of mistakes can be called an error. This is the difference of what we called 'mistake' and 'error' in language learning.

I do agree when someone said that mistake is a part of learning process. Dr. Alaadin K. Abdullah and
Ghanim M. Hussein found out that the difficulties of learning English for EFL students are as follows.

- There are some problems or difficulties with vocabulary.

- There are some problems or difficulties with writing essay.

- There are some problems or difficulties with the item "using different structures of sentence."

Due to this findings, it means that EFL students face some problem in learning English.

As foreign language learners, we sometimes make errors while learning. Therefore we get something to learn, what dos and donts. In bahasa Indonesia, a sentence consists of Subject + Predicate + Object, in English a sentence consists of $\mathrm{S}$ and V/P. From this case, we know that not only having differences in sounds, the language structure between First and Target language is also different. When learning a language, we must learn the language structure too. I found it hard when I have to see so many formulas to form some sentences. But, because it is a part of language learning, we cannot avoid this process. In bahasa Indonesia, we learn sentences, clauses, phrases; what they are, how they form. As a foreign language learners, we also learn how to form a sentence, how to write well in English.

When learning grammar/structure, we cannot skip the process of learning clauses. A clause can be a sentence too, it consists of at least one Subject and one Verb. There are two kinds of clause: independent and dependent clause. When we form an independent clause we just have to follow the 
pattern just like when we write a sentence. It is a bit different when we write dependent clause. From its definition, it is clear that dependent clause cannot stands alone, it must be related to independent clause. So, It means that there must some kind of words that connect the dependent clause to the independent clause.

Referring to research done by Nur Baithy (An Analysis of Students' Error in Learning Noun Clause) she analyzed the errors that the students made in noun clause. She found that students made many errors, it means that they found some difficulties while constructing noun clause. We're not talking about how to form clauses. What I am focused on to be analyzed in here is the nominal clause. Since I have explained that sometimes as foreign language learners we made errors, this kind of errors can be found in many areas of language skills and components. Learning English grammar is one of the hardest parts of learning English. Clauses are really interested to be discussed, especially dependent clause. Although there are many types of dependend clause, I am interested in analyzing students' errors in constructing nominal clause.

\section{Theoretical Review}

\section{Errors}

James (1998:6) claims that Error analysis is the process of determining the incidence, nature, causes, and consequences of unsuccessful language. This opinion can be interpreted that the error analysis is a process that determines the occurrence of errors that are either naturally or because of something else, and the consequences of failure in learning the language. Errors are natural characteristics which happen in process of language acquisition and learning. Especially in English learning, errors are difficult to avoid. There are many definitions of errors presented by experts. Basically, those contains the same meaning while the difference lies on how they formulate them.

Brown (in Choiriyah, 2007: 20) said "in learning a foreign language, learners are involved in the process of approximations to the system used by the native speaker of the language. It shows that making errors is natural and is one of process in learning which cannot be avoided by every learner.

According to Norrish (in Choiriyah, 2007: 19), error is a systematic deviation, when a learner has not learnt something and consistently gets it wrong. In line with the definition above, Cunninghworth (in Choiriyah, 2007: 20), states that errors are systematic deviations from the norms of the language being learned. Errors are flawed side caused by lack of knowledge of the rules of the language. Chomsky calls such errors as competence errors. In line with Chomsky, Brown states that errors reflect the competence of the learner. In the process of learning a foreign language, making errors is inseparable. Furthermore, Dulay, et.al, (Choiriyah, 2007), errors are defined as the flawed side of learners' speech or writing, which deviates from come selected norm of mature language performance.

From the definitions above clarify that error analysis is an activity to identify, classify and interpreted or describe the errors made by someone in speaking or in writing and it is carried out to obtain information on common difficulties faced by someone in speaking or in writing English sentences. Another thing which should be noticed is the procedure of error analysis.

According to Corder, errors divided into four categories: omission of some required element, addition of some necessary or incorrect element, selection of an incorrect element, and miss-ordering of element. And here are the explanations:

1) Omission

Certain linguistic forms may be omitted by the learners because of their complexity in production. Omission also occurs in morphology. Learners often leave out the third person singular morpheme $-\mathrm{s}$, the plural marker $-\mathrm{s}$ and the past tense inflection -ed.

2) Addition

Learners not only omit elements which they regard as redundant but they also add redundant element.

3) Selection

Learners commit errors in pronunciation, morphology, syntax and vocabulary due to the selection of the wrong, phoneme, morpheme, structure or vocabulary item.

4) Ordering

Miss-ordering can occur in morphological level. Miss-ordering of bound morpheme in English is perhaps less frequent, given their limited number.

Students' errors may be distinguished as follows:

1) Errors Performance is unsystematic and not very serious, because the students themselves can correct them when their attention is drawn to them. These errors are attributed to carelessness, lapse of memory, ill health, emotional health, etc., and they should not worry us.

2) Errors Competence is persistent and systematic and in consequence serious, and their treatment calls for careful analysis to discover their cause. These errors represent the learners' traditional competence (Michealides, 1990:98) Gass and Selinker (2001:79) state that "A great deal of the work on error analysis was carried out within the context of the classroom. The goal was clearly one of pedagogical remediation. According to Selinker and Gass (2001:79) there are number of steps taken in conducting an error analysis:

1) Identify errors, what is the error (e.g. incorrect sequence of tenses, wrong verb form, etc)

2) Classify errors. Is it an error of Tense? Is it an error in sentence pattern? 
3) Quantify errors. How many errors of Tense occur?

4) Analysis of source/causes.

5) Remediation. Based on the kind and frequency of an error type, pedagogical intervention is carried out.

\section{Nominal Clause}

Nominal clause (noun clause) is a subordinate clause used as a noun in the sentence. A noun clause may be used as a subject or direct object of the verb, as a predicate noun, as object of the preposition, or as an appositive. Every direct quotation is a noun clause without an introductory word. Mary said, "Dinner is ready." (The noun clause is the object of said.) Mary said that dinner was ready. (That is the introductory word.)

Nordquist in grammar.about.com states "in English grammar, a noun clause is a dependent clause that functions as a noun (that is, as a subject, object, or complement) within a sentence. Also known as a nominal clause. Two common types of noun clause in English are that-clauses and wh-clauses:

- that-clause: I believe that everything happens for a reason.

- $\quad$ wh-clause: How do I know what I think, until I see what I say?

Moreover, in a site faculty.unlv.edu Complementation is the formation of nominal constituents. These constituents are dependent clauses that fill sentence positions (slots) normally reserved for noun phrases. The most common nominal clauses are (complementizer) that-clauses and interrogative clauses. As dependent clauses, that-clauses and interrogative clauses have a subject and a main verb and rarely require punctuation.

Types of Nominal Clause

1. Noun Clauses Beginning with a Question Word

An interrogative clause is a nominal dependent clause beginning with an interrogative word and usually involving a question, directed at either oneself or to another, about an unknown.

Example:

W-H Question

Noun Clause

a. What did he say? I

couldn't hear what he said.

b. Where does she live? I don't know where she lives.

c. Who is at the door? I wonder who is at the door.

d. When will the train arrive? I know when the train will arrive.

e. Whose house is that? I wonder whose house that is.

2. Noun Clauses Beginning with Whether or If Yes/No Question

Noun Clause a. Will she come? I don't know whether she will come (or not).

I don't know if she will come (or not).

b. Does he need help? I wonder whether he needs help (or not).

I wonder if he needs help (or not).

\section{Question Words followed by Infinitives}

Question words (when, where, what, why, who, whose, whom, which, how, and whether) may be followed by infinitive. Each pair of sentences in the examples has the same meaning. The meaning expressed by the infinitive is either should or can/could.

\section{NC with W-H Question}

NC with Infinitives

a. I don't know what I should do. I don't know what to do.

b. Jim told us where we could find it. Jim told us where to find it.

c. Sally told me when I should come. Sally told me when to come.

4. Noun Clauses beginning with That A that-clause is a dependent clause beginning with the expletive that and functioning nominally; that may be deleted. Verb + That - Clause.

Example:

a. The truth was that the moving company lost all your furniture.

The truth was the moving company lost all your furniture.

b. I am pleased that you are studying noun clauses.

I am pleased you are studying noun clauses.

Nominal clauses perform nominal functions, or functions prototypically performed by noun phrases. In other words, they can do anything that a noun can do.

\section{Research Purpose}

The purpose of the study is to analyze students' error in constructing nominal clause. There are two benefits from this study. Theoretically, the benefit of the study is to add reference at the same topic area. Practically, the benefits of the study are: students will know the errors that they usually make therefore they can revise it and later they will avoid doing the same mistake, lecturers know the problem of the students therefore they will focus on this problem to decrease the number of errors that students make.

\section{RESEARCH METHOD}

This research is conducted qualitative method descriptively. Descriptive research, according to Gay (2000: 275) is a study to determine and describe the way things are. The population for this research is 
the third semester students of English Education department at Indraprasta PGRI University. There are two classes which consist of 30 students for each, therefore the population of this research is 60 students. The technique of sample taking is random sampling. There are 15 students which is 25 percent of the population as a sample from the two classes are taken randomly. The field research is used to collect the data. To get field research, I get in touch directly with the students of Indraprasta PGRI University.

A simple grammar test of nominal clause is given to the third semester student of the two classes to know how far the students are able to do the nominal clause test. Then, I use many books, papers, and the data from the internet related to the research to support the theoretical framework. The test is given for the students of the two classes in different time. The students do the test in the classroom. The students are given 60 minutes for completing the test. I classify the grammar errors into four parts: Noun Clause beginning with questions words, noun clause beginning of whether or if, noun clause with question words followed by infinitives, and noun clause beginning with 'that'. I calculate the errors using simple statistic formula, and the data will be explained in description analysis. Then, I use books and other materials such as the data from internet which have topic related to this study that support the discussion. Descriptive analysis technique is used (percentage) with the percentage from the frequency of information and divided with number of cases. The formula is:

$$
\begin{aligned}
& \mathrm{P}=\frac{\mathrm{F} X 100 \%}{\mathrm{~N}} \\
& \text { Notes: } \\
& \text { P: Percentage } \\
& \mathrm{F} \text { : Frequency of wrong answer } \\
& \mathrm{N} \text { : Number of sample }
\end{aligned}
$$

\section{FINDINGS AND DISCUSSIONS}

\section{Findings}

The grammar errors are classified into four parts: Noun Clause beginning with questions words, noun clause beginning of whether or if, noun clause with

\begin{tabular}{|c|c|c|c|c|c|}
\hline \multirow{2}{*}{$\begin{array}{l}N \\
0\end{array}$} & \multirow{2}{*}{$\begin{array}{c}\text { Question } \\
\text { Words }\end{array}$} & \multicolumn{2}{|c|}{ Nominal Clause } & \multirow{2}{*}{\begin{tabular}{|c|} 
Type \\
of \\
Errors
\end{tabular}} & \multirow{2}{*}{$\begin{array}{c}\text { No of } \\
\text { Errors } \\
(\%)\end{array}$} \\
\hline & & Students' Work & Reconstruction & & \\
\hline 1 & $\begin{array}{l}\text { When are } \\
\text { they coming? }\end{array}$ & $\begin{array}{l}\text { Do you know } \\
\text { 'when they } \\
\text { coming are' }\end{array}$ & $\begin{array}{l}\text { Do you know } \\
\text { 'when they are } \\
\text { coming' }\end{array}$ & 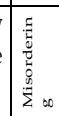 & $\begin{array}{l}12 / 15 \\
(80 \%)\end{array}$ \\
\hline 2 & $\begin{array}{l}\text { Which one } \\
\text { does he want? }\end{array}$ & $\begin{array}{l}\text { Let's ask him } \\
\text { 'which one he } \\
\text { want.' }\end{array}$ & $\begin{array}{l}\text { Let's ask him } \\
\text { 'which one he } \\
\text { wants.' }\end{array}$ & $\begin{array}{l}5 \\
\frac{0}{6} \\
\frac{6}{2} \\
0 \\
0\end{array}$ & \begin{tabular}{|l|}
$8 / 15$ \\
$(53 \%)$
\end{tabular} \\
\hline 3 & $\begin{array}{l}\text { Why did they } \\
\text { leave the } \\
\text { country? }\end{array}$ & $\begin{array}{l}\text { 'Why they leave } \\
\text { the country' is a } \\
\text { secret. }\end{array}$ & $\begin{array}{l}\text { 'Why they left } \\
\text { the country' is a } \\
\text { secret. }\end{array}$ & 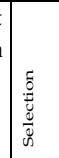 & \begin{tabular}{|l|}
$8 / 15$ \\
$(53 \%)$
\end{tabular} \\
\hline 4 & $\begin{array}{l}\text { Who are } \\
\text { those people? }\end{array}$ & $\begin{array}{l}\text { I don't know } \\
\text { 'who those are } \\
\text { people.' }\end{array}$ & $\begin{array}{l}\text { I don't know } \\
\text { 'who those } \\
\text { people are.' }\end{array}$ & 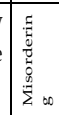 & $\begin{array}{l}10 / 15 \\
(67 \%)\end{array}$ \\
\hline 5 & $\begin{array}{l}\text { Whose pen is } \\
\text { this? }\end{array}$ & $\begin{array}{l}\text { Do you know } \\
\text { 'whose pen is } \\
\text { this?' }\end{array}$ & $\begin{array}{l}\text { Do you know } \\
\text { 'whose pen this } \\
\text { is?' }\end{array}$ & 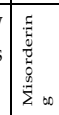 & $\begin{array}{l}8 / 15 \\
(53 \%)\end{array}$ \\
\hline 6 & $\begin{array}{l}\text { Who opened the } \\
\text { door? }\end{array}$ & $\begin{array}{l}\text { I don't know } \\
\text { 'whose open the } \\
\text { door.' }\end{array}$ & $\begin{array}{l}\text { I don't know 'who } \\
\text { opened the door.' }\end{array}$ & 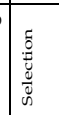 & $\begin{array}{l}6 / 15 \\
(40 \%)\end{array}$ \\
\hline 7 & $\begin{array}{l}\text { Where did she } \\
\text { go? }\end{array}$ & $\begin{array}{l}\text { 'where she goes' is } \\
\text { none of your } \\
\text { bussiness. }\end{array}$ & $\begin{array}{l}\text { 'where she went' is } \\
\text { none of your } \\
\text { bussiness. }\end{array}$ & 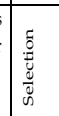 & \begin{tabular}{|l|}
$8 / 15$ \\
$(53 \%)$
\end{tabular} \\
\hline 8 & \begin{tabular}{|l|}
$\begin{array}{l}\text { What } \\
\text { happened? }\end{array}$ \\
\end{tabular} & \begin{tabular}{|l|} 
I don't know 'what \\
washappened?
\end{tabular} & $\begin{array}{l}\text { I don't know what } \\
\text { happened? }\end{array}$ & 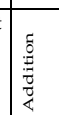 & $\begin{array}{l}7 / 15 \\
(47 \%)\end{array}$ \\
\hline 9 & $\begin{array}{l}\text { What are they } \\
\text { doing in class? }\end{array}$ & $\begin{array}{l}\text { 'What are they } \\
\text { doing in class' is } \\
\text { easy. }\end{array}$ & $\begin{array}{l}\text { What they are } \\
\text { doing in class is } \\
\text { easy. }\end{array}$ & 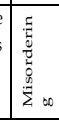 & \begin{tabular}{|l|}
$8 / 15$ \\
$(53 \%)$
\end{tabular} \\
\hline 10 & $\begin{array}{l}\text { What was he } \\
\text { talking about? }\end{array}$ & $\begin{array}{|lr|}\text { 'What he } & \text { talking } \\
\text { about' } & \text { was } \\
\text { interesting. } & \\
\end{array}$ & $\begin{array}{l}\text { What he was } \\
\text { talking about was } \\
\text { interesting. }\end{array}$ & $\begin{array}{l}5 \\
0 \\
5 \\
.0 \\
\tilde{\Xi} \\
0\end{array}$ & $\begin{array}{l}6 / 15 \\
(40 \%)\end{array}$ \\
\hline
\end{tabular}
question words followed by infinitives, and noun clause beginning with 'that'.
Table 1. Noun Clauses Beginning with Question Word

The result shows that students make errors while constructing Nominal clause. In sentence 1, 4, 5, 9 more than 6 out of 15 students make error while constructing nominal clause, the type of error that they make is categorized into misordering error. In sentence 2 and 10, 8 out of 15 students make error while contructing nominal clause, the type of error that they make is categorized into omission error.In sentence 3, 6, 7, more than 6 make error while constructing nominal clause, the type of error that they make is categorized into selection error. In sentence 8,7 out of 15 students make error while contructing nominal clause, the type of error that they make is categorized into addition error. 
Table 2. Noun Clauses Beginning with Whether/If

\begin{tabular}{|c|c|c|c|c|c|}
\hline \multirow[b]{2}{*}{$\begin{array}{l}\mathrm{N} \\
0\end{array}$} & \multirow{2}{*}{$\begin{array}{c}\text { Yes/No } \\
\text { Question }\end{array}$} & \multicolumn{2}{|c|}{ Nominal Clause } & \multirow{2}{*}{\begin{tabular}{|c|} 
Type \\
of \\
Error \\
$s$
\end{tabular}} & \multirow{2}{*}{$\begin{array}{l}\text { No of } \\
\text { Error } \\
\mathrm{s}(\%)\end{array}$} \\
\hline & & Students' Work & Reconstruction & & \\
\hline 1 & $\begin{array}{l}\text { Is the } \\
\text { financial } \\
\text { report } \\
\text { ready? }\end{array}$ & $\begin{array}{l}\text { Let me know if } \\
\text { the financial } \\
\text { report ready.' }\end{array}$ & $\begin{array}{l}\text { Let me know 'if } \\
\text { financial report } \\
\text { is ready.' }\end{array}$ & 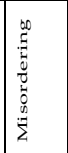 & $\begin{array}{l}10 / 15 \\
(67 \%)\end{array}$ \\
\hline 2 & $\begin{array}{l}\text { Will it be } \\
\text { ready } \\
\text { tomorrow? }\end{array}$ & $\begin{array}{l}\text { Let me know 'if } \\
\text { it be ready } \\
\text { tomorrow.' }\end{array}$ & $\begin{array}{l}\text { Let me know 'if } \\
\text { it will be ready } \\
\text { tomorrow.' }\end{array}$ & 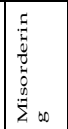 & $\begin{array}{l}7 / 15 \\
(47 \%)\end{array}$ \\
\hline 3 & $\begin{array}{l}\text { Does the } \\
\text { copy } \\
\text { machine } \\
\text { need paper? }\end{array}$ & \begin{tabular}{|l}
\multicolumn{2}{|l|}{ Let me know 'if } \\
the copy \\
machine need \\
paper.'
\end{tabular} & $\begin{array}{l}\text { Let me know 'if } \\
\text { the copy } \\
\text { machine needs } \\
\text { paper.' }\end{array}$ & $\begin{array}{l}0 \\
0 \\
0 \\
0 \\
\tilde{g} \\
0 \\
0\end{array}$ & $\begin{array}{l}8 / 15 \\
(53 \%)\end{array}$ \\
\hline 4 & $\begin{array}{l}\text { Is someone } \\
\text { waiting for } \\
\text { me? }\end{array}$ & $\begin{array}{l}\text { Let me know if } \\
\text { someone waited } \\
\text { for me'. }\end{array}$ & $\begin{array}{l}\text { Let me know 'if } \\
\text { someone is } \\
\text { waiting for me'. }\end{array}$ & 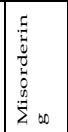 & $\begin{array}{l}6 / 15 \\
(40 \%)\end{array}$ \\
\hline 5 & $\begin{array}{l}\text { Are you } \\
\text { going to be } \\
\text { there? }\end{array}$ & $\begin{array}{l}\text { Let me know if } \\
\text { you went to be } \\
\text { there'. }\end{array}$ & $\begin{array}{l}\text { Let me know 'if } \\
\text { you are going to } \\
\text { be there'. }\end{array}$ & 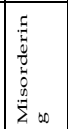 & $\begin{array}{l}8 / 15 \\
(53 \%)\end{array}$ \\
\hline 6 & $\begin{array}{l}\text { Is there any } \\
\text { paper left? }\end{array}$ & $\begin{array}{l}\text { Please check } \\
\text { 'whether there } \\
\text { any paper left'. }\end{array}$ & $\begin{array}{l}\text { Please check } \\
\text { 'whether there is } \\
\text { any paper left'. }\end{array}$ & \begin{tabular}{|l|}
0 \\
0 \\
0 \\
$\tilde{c}$ \\
0 \\
0
\end{tabular} & $\begin{array}{l}7 / 15 \\
(47 \%)\end{array}$ \\
\hline 7 & $\begin{array}{l}\text { Did the fax } \\
\text { come in? }\end{array}$ & $\begin{array}{l}\text { Let me know } \\
\text { 'whether the fax } \\
\text { come in'. }\end{array}$ & $\begin{array}{l}\text { Let me know } \\
\text { 'whether the fax } \\
\text { came in'. }\end{array}$ & 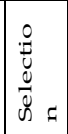 & $\begin{array}{l}8 / 15 \\
(53 \%)\end{array}$ \\
\hline 8 & $\begin{array}{l}\text { Is the } \\
\text { information } \\
\text { correct? }\end{array}$ & $\begin{array}{l}\text { Please check } \\
\text { 'whether the } \\
\text { information } \\
\text { correct'. }\end{array}$ & $\begin{array}{l}\text { Please check } \\
\text { 'whether the } \\
\text { information is } \\
\text { correct'. }\end{array}$ & 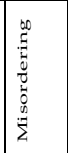 & $\begin{array}{l}12 / 15 \\
(80 \%)\end{array}$ \\
\hline
\end{tabular}

The result shows that students make errors while contructing Nominal clause. In sentence 1, 2, 4, 5,8, more than 6 students make error while constructing nominal clause, the type of error that they make is categorized into misordering error. In sentence 3and 6, 8 out of 15 students make error while contructing nominal clause, the type of error that they make is categorized into omission error. In sentence 7,8 out of 15 students make error while constructing nominal clause, the type of error that they make is categorized into selection error.
Table 3. Noun Clauses with Infinitives

\begin{tabular}{|c|c|c|c|c|c|}
\hline \multirow[b]{2}{*}{$\begin{array}{l}\mathrm{N} \\
\mathrm{o}\end{array}$} & \multirow{2}{*}{$\begin{array}{c}\text { Question words } \\
\text { followed by } \\
\text { should/could }\end{array}$} & \multicolumn{2}{|c|}{ Nominal Clause } & \multirow{2}{*}{$\begin{array}{c}\text { Type } \\
\text { of } \\
\text { Errors }\end{array}$} & \multirow{2}{*}{$\begin{array}{c}\text { No of } \\
\text { Errors } \\
(\%)\end{array}$} \\
\hline & & \begin{tabular}{|l} 
Students' \\
Work
\end{tabular} & \begin{tabular}{|l|} 
Reconstructio \\
$\mathrm{n}$
\end{tabular} & & \\
\hline 1 & $\begin{array}{l}\text { Sally told me } \\
\text { when I should } \\
\text { come. }\end{array}$ & $\begin{array}{l}\text { Sally told me } \\
\text { when should } \\
\text { come. }\end{array}$ & $\begin{array}{l}\text { Sally told me } \\
\text { when to come. }\end{array}$ & 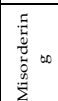 & $\begin{array}{l}12 / 15 \\
(80 \%)\end{array}$ \\
\hline 2 & $\begin{array}{l}\text { The plumber } \\
\text { told me how I } \\
\text { could fix the } \\
\text { leak in the sink. }\end{array}$ & $\begin{array}{l}\text { The plumber } \\
\text { told me how } \\
\text { fixing the leak } \\
\text { in the sink. }\end{array}$ & $\begin{array}{l}\text { The plumber } \\
\text { told me how to } \\
\text { fix the leak in } \\
\text { the sink. }\end{array}$ & 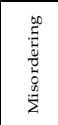 & \begin{tabular}{|l}
$7 / 15$ \\
$(47 \%)$
\end{tabular} \\
\hline 3 & $\begin{array}{l}\text { Please tell me } \\
\text { where I should } \\
\text { meet you. }\end{array}$ & $\begin{array}{l}\text { Please tell me } \\
\text { where should I } \\
\text { meet you. }\end{array}$ & $\begin{array}{l}\text { Please tell me } \\
\text { where to meet } \\
\text { you. }\end{array}$ & 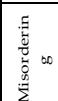 & \begin{tabular}{|l|}
$7 / 15$ \\
$(47 \%)$
\end{tabular} \\
\hline 4 & $\begin{array}{l}\text { Robert had a } \\
\text { long excuse for } \\
\text { being late for } \\
\text { their date, but } \\
\text { Sandy didn't } \\
\text { know whether } \\
\text { she should } \\
\text { believe him or } \\
\text { not. }\end{array}$ & $\begin{array}{l}\text { Robert had a } \\
\text { long excuse for } \\
\text { being late for } \\
\text { their date, but } \\
\text { Sandy didn't } \\
\text { know if believe } \\
\text { him or not. }\end{array}$ & $\begin{array}{l}\text { Robert had a } \\
\text { long excuse for } \\
\text { being late for } \\
\text { their date, but } \\
\text { Sandy didn't } \\
\text { know whether } \\
\text { to believe him } \\
\text { or not. }\end{array}$ & 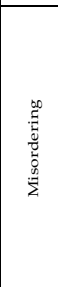 & \begin{tabular}{|l|}
$8 / 15$ \\
$(53 \%)$
\end{tabular} \\
\hline 5 & $\begin{array}{l}\text { I don't know } \\
\text { what else I can } \\
\text { do. }\end{array}$ & $\begin{array}{l}\text { I don't know } \\
\text { what else I can } \\
\text { do. }\end{array}$ & $\begin{array}{l}\text { I don't know } \\
\text { what else to do. }\end{array}$ & 1 & \begin{tabular}{|l|}
$7 / 15$ \\
$(47 \%)$
\end{tabular} \\
\hline
\end{tabular}

The result shows that students make errors while constructing Nominal clause. In sentence 1, 2, 3, 4, more than 6 students make error while constructing nominal clause, the type of error that they make is categorized into misordering error.

Table 4. Noun Clauses beginning with That

\begin{tabular}{|c|c|c|c|c|c|}
\hline \multirow{2}{*}{$N$} & \multirow[b]{2}{*}{ That-Clause } & \multicolumn{2}{|c|}{ Nominal Clause } & \multirow{2}{*}{$\begin{array}{l}\text { Type } \\
\text { of } \\
\text { Errors }\end{array}$} & \multirow{2}{*}{$\begin{array}{l}\text { No of } \\
\text { Errors }\end{array}$} \\
\hline & & Students' Work & \begin{tabular}{|l|} 
Reconstructio \\
$\mathrm{n}$
\end{tabular} & & \\
\hline 1 & \begin{tabular}{|l|} 
I sometimes \\
forget that ...... \\
(class, start)
\end{tabular} & $\begin{array}{l}\text { I sometimes } \\
\text { forget that my } \\
\text { class } \\
8 \text { starting at } \\
8 .\end{array}$ & \begin{tabular}{|l} 
I sometimes \\
forget that my \\
class starts at 8.
\end{tabular} & 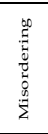 & $\begin{array}{l}8 / 15 \\
(53 \%)\end{array}$ \\
\hline 2 & $\begin{array}{|lr|}\text { I recently } \\
\text { heard } & \text { on the } \\
\text { news } & \text { that } \\
\text { (Trump, wi... }\end{array}$ & $\begin{array}{l}\text { I recently heard } \\
\text { on the news that } \\
\text { Trump win U.S } \\
\text { presidential } \\
\text { election. }\end{array}$ & $\begin{array}{lr}\text { I recently } \\
\text { heard } & \text { on the } \\
\text { news } & \text { that } \\
\text { Trump r wins } \\
\text { U.S } \\
\text { presidential } \\
\text { election. }\end{array}$ & $\begin{array}{l}0 \\
0 \\
0 \\
0 \\
0 \\
0\end{array}$ & $\begin{array}{l}8 / 15 \\
(53 \%)\end{array}$ \\
\hline 3 & 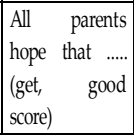 & $\begin{array}{l}\text { All parents hope } \\
\text { that their } \\
\text { children got a } \\
\text { good score. }\end{array}$ & $\begin{array}{l}\text { All parents } \\
\text { hope that their } \\
\text { children get a } \\
\text { good score. }\end{array}$ & 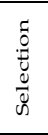 & $\begin{array}{l}10 / 15 \\
(67 \%)\end{array}$ \\
\hline 4 & $\begin{array}{|lr|}\text { Have r } & \text { you } \\
\text { notice } & \text { that .....? } \\
\text { (have, } & \text { new } \\
\text { hairstyle) } & \\
\end{array}$ & $\begin{array}{l}\text { Have you notice } \\
\text { that Diana have } \\
\text { a new hairstyle? }\end{array}$ & \begin{tabular}{|lr} 
Have & you \\
notice & that \\
Diana has a & has \\
new hairstyle?
\end{tabular} & 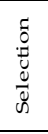 & $\begin{array}{l}8 / 15 \\
(53 \%)\end{array}$ \\
\hline 5 & \begin{tabular}{|l|} 
Students \\
understand \\
that \\
(assignment, \\
submit)
\end{tabular} & $\begin{array}{l}\text { Students } \\
\text { understand that } \\
\text { the assignment } \\
\text { is submit this } \\
\text { Friday. }\end{array}$ & \begin{tabular}{|l} 
Students \\
understand \\
that the \\
assignment \\
must be \\
submitted this \\
Friday.
\end{tabular} & 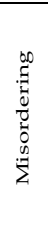 & $\begin{array}{l}12 / 15 \\
(80 \%)\end{array}$ \\
\hline
\end{tabular}

The result shows that students make errors while contructing Nominal clause. In sentence 1 and 5, 
more than 8students make error while constructing nominal clause, the type of error that they make is categorized into misordering error. In sentence 2, 8 out of fifteen students make error while constructing nominal clause, the type of error that they make is categorized into omission error. In sentence 3 and 4, 8 out of fifteen students make error while constructing nominal clause, the type of error that they make is categorized into selection error.

\section{Discussion}

Here is the explanation of the findings.

Noun Clauses Beginning with a Question

Word

An interrogative clause is a nominal dependent clause beginning with an interrogative word and usually involving a question, directed at either oneself or to another, about an unknown. Related to the finding, the discussions are as follow.

\section{W-H Question \\ Noun Clause}

a.When are, they coming? Do you know when they are coming?

NC

b.Which one does he want? Let's ask him which one he wants.

NC

c. Why did they leave the country? Why they left the country is a secret.

NC

d.Who are those people? I don't know who those people are.

NC

e. Whose pen is this?

Do you know whose pen this is?

f. Who opened the door? I don't know who opened the door

NC

g.Where did she go? Where she went is none of your bussiness.

h.What happened? I don't know what happened.

NC

i. What are they doing? What they are doing is easy.

j. What was he talking about? What he was talking about was interesting.

In spite of the type of errors that the sudents' make in constructing Nominal clause as table shows, it can be said that most students are still confused how to construct the Noun Clause beginning with Question words. The pattern of NC is W-H Questions + S + V. For example:
Whose pen is this?

Do you know whose pen is this?

(incorrect)

Q.word auxV S

Do you know whose pen this is? (correct)

Q.word S auxV

- Noun Clauses Beginning with Whether or If The pattern of Noun Clause beginning with whether or ifis whether/if $+\mathbf{S}+\mathbf{V}$. Related to the finding, the discussions are as follow.

\section{Yes/No Question}

Noun Clause

a. Is the financial report ready? Let me know if financial report is ready.

NC

b. Will it be ready tomorrow? Let me know if it will be ready tomorrow.

NC

c. Does the copy machine need paper? Let me know if the copy machine needs paper. $\mathrm{NC}$

d. Is someone waiting for me? Let me know if someone is waiting for me. $\mathrm{NC}$

e. Are you going to be there? Let me know if you are going to be there.

NC

f. Is there any paper left?Please check whether there is any paper left. NC

g. Did the fax come in? Let me know whether the fax came in. $\mathrm{NC}$

h. Is the information correct? Please check whether the information is correct. NC

In spite of the type of errors that the sudents' make in constructing Nominal clause as the table shows, it can be said that most students understand well how to construct noun clause beginning with whether/if but the they make some errors of using appropriate verb. For example:

Did the fax come in?

Let me know whether the fax come in. (incorrect)

Let me know whether the fax came in. (correct)

- Question Words followed by Infinitives

Question words (when, where, what, why, who, whose, whom, which, how, and whether) may be followed by infinitive. Each pair of sentences has the same meaning. The meaning expressed by the infinitive is either should or can/could.

a. Sally told me when I should come. Sally told me when to come. 
b. The plumber told me how I could fix the leak in the sink.

The plumber told me how to fix the leak in the sink.

c. Please tell me where I should meet you. Please tell me where to meet you.

d. Robert had a long excuse for being late for their date, but Sandy didn't know whether she should believe him or not.

Robert had a long excuse for being late for their date, but Sandy didn't know whether to believe him or not.

e. I don't know what else I can do. I don't know what else to do.

In spite of the type of errors that the sudents' make in constructing Nominal clause as the table shows, it can be said that most students understand well how to construct noun clause beginning with $\mathrm{Q}$ Words follow by should/could. The meaning expressed by the infinitive is either should or can/could, but some students are still confused to change the use of should/could with to - infinitive. For example:

Robert had a long excuse for being late for their date, but Sandy didn't know whether she should believe him or not.

- $\quad$ Robert had a long excuse for being late for their date, but Sandy didn't know if believe him or not. (incorrect)

- $\quad$ Robert had a long excuse for being late for their date, but Sandy didn't know whether to believe him or not. (correct)

- Noun Clauses beginning with That

A that-clause is a dependent clause beginning with the expletive that and functioning nominally; thatmay be deleted.Verb + That Clause.

a. I sometimes forget that ...... (class, start) I sometimes forget that my class starts at 8 .

b. I recently heard on the news that ..... (Trump, win)

I recently heard on the news that Trump wins U.S presidential election.

c. All parents hope that ..... (get, good score) All parents hope that their children get a good score.

d. Have you notice that .....? (have, new hairstyle) Have you notice that Diana has a new hairstyle?

e. Students understand that ...... (assignment, submit)

Students understand that the assignment must be submitted this Friday.

In spite of the type of errors that the sudents' make in constructing Nominal clause as the table shows, it can be said that most students understand well how to construct noun clause with that-clause, but some students make grammatical error. For example:

I sometimes forget that ...... (class, start)
- $\quad$ I sometimes forget that my class starting at 8 . (incorrect)

- $\quad$ I sometimes forget that my class starts at 8. (correct)

\section{CONCLUSION}

Errors in foreign language teaching especially in English are the cases which are difficult enough to avoid. Many aspects that can cause the learners of English as a foreign language make errors. The result shows that students make errors while contructing Nominal clause beginning with Question words, Nominal Clause with If/Whether, Nominal Clause with -that. In spite of the type of errors that the sudents' make in constructing Nominal clause, here are the conclusion:

- $\quad$ Nominal Clause beginning with Q-Word: most students are still confused how to put sentence pattern correctly.

- Nominal clause beginning with whether/if: students understand well how to construct nominal clause beginning with whether/if but they make some errors of using approriate verb.

- Nominal clause beginning with Q Words follow by should/could: most students understand well how to construct noun clause beginning with $\mathrm{Q}$ Words follow by should/could. The meaning expressed by the infinitive is either should or can/could, but some students are still confused to change the use of should/could with to infinitive.

- Nominal clause beginning with -that: most students understand well how to constuct noun clause with that-clause, but some students make grammatical error while constructing the clause.

\section{REFERENCES}

Azhar, Betty S and Stacy A. Hagen. (2009). Understanding and Using English Grammar fourth edition. New York: Pearson Longman.

James, C. (1998). Error in Language Learning and Use: Exploring Error Analysis. New York: Longman.

Gass, Susan. M and Larry Selinker. (2001). Second Language Acquisition: An Introductory Course. New York: Taylor \& Francis.

Rosani, Ahmad. (2008). Contrastive Linguistics and Error Analysis. Jakarta: English Department Language Faculty and Art Indrapasta University.

Setyawati. (2010). Analisis Kesalahan Berbahasa Indonesia. Surakarta: Yuma Pustaka.

Sugiyono. (2012). Metode Penelitian Kuantitatif Kualitatif dan R\&D. Bandung: Alfabeta. 
Tarigan, Henry G. (2008). Menulis Sebagai Sebuah Keterampilan Berbahasa. Bandung: Angkasa.

\section{Inter Net}

Choiriyah, Neneng. 2007. Manajemen Kearsipan www.a-research.upi.edu

Michealides. 1990. "Evaluating Grammar Development through Longitude Error Analysis of English Major Students." www.alaqsa.edu.ps
Nordquish, Robert. 2016.

http://grammar.about.com/od/mo/g/nounclauset erm.htm

http://www1.sil.org/linguistics/glossaryoflinguisticte rms/WhatIsANominalClause.htm

http://www.learnenglish.de/grammar/clausetext.html

https://faculty.unlv.edu/nagelhout/ENG411Bs12C/m od3concept5.html 